\title{
An Analysis of Service Failures and Recovery Strategies in the Turkish Third Party Logistics Service Industry
}

\author{
Nazlı Gülfem Gidener, Durmuş Ali Deveci
}

Service literature indicates that both service failure and service recovery have a strong impact on the business relationships between service providers and their customers. The purpose of this research is twofold: to explore and analyze the most common service failures and implemented recovery strategies in Turkish third party logistics service industry and examine their impact on business relationships. Critical Incident Technique (CIT) was used. Thus, information on critical incidents were collected from both third party logistics service providers (3PLs) and their customers, failures and recovery strategies were categorized and the impact of service failures and recovery strategies on future relationships between customers and 3PLs examined. The findings indicate that service failures are most frequently encountered in customer services and port operations and that symbolic service recovery is the most common recovery strategy implemented by third party logistics service providers. The findings also show that third party logistics service providers and carriers are the most common sources of failure in third party logistics services.

\section{KEY WORDS}

$\sim$ Service Failure

$\sim$ Service Recovery

$\sim$ Third Party Logistics Service Providers

$\sim$ Business-to-Business Relationships

$\sim$ Critical Incident Technique

Dokuz Eylul University, Izmir, Turkey

e-mail: ggidener@gmail.com

doi: 10.7225/toms.v09.n01.003

This work is licensed under (cc) BY

\section{INTRODUCTION}

The service market is steadily growing in industrialized countries and even though the products of service market actors are intangible and non-physical, they engage in physical distribution activities and make decisions (Ballou, 2004: 21). Furthermore, services are thought to account for up to $70-85 \%$ of the GDP of developed nations (Johnston\& Michel, 2008). Service industry tends to grow and develop in parallel with changes such as technological advancements, mobilization of knowledge, globalization and ever increasing competition, making it harder for businesses to survive (Özgüven, 2008).

Therefore, service markets are affected by the recent increase in competition between service companies (Payne, 1993). Since service provision implies interpersonal interaction and the involvement of customers in the service production process, the most likely consequence of the inability to standardize employee actions are service quality management problems (Öztürk, 2000). Considering the competitiveness levels and the aforementioned inability to standardize employee actions, sustaining high service quality is of paramount importance in service industries in general and in the third party logistics service industry in particular.

Furthermore, transportation and additional logistics services provided by 3PLs make up the economy of a country whilst transforming raw materials into finished goods using an effective international physical distribution system and a solid supply chain (Rojas, 2018). Likewise, the importance of supply chain sustainability and green image for profitability is frequently underlined by undisrupted supply (Russel et al., 2018). However, as more means of transportation or participants get 
involved, coordination becomes a challenge with respect to the maintenance of service quality, speed and reliability (Dua and Sinha, 2019). Consequently, the crucial importance of 3PL service failures, which disrupt the supply chain and decrease the said effectiveness as a whole, is evident.

The need for expansion of B2B studies in the framework of service failure and recovery research was frequently emphasized. There has been no extensive research of switching behaviors in the B2B context, studies including both satisfied and dissatisfied customers after recoveries are few and finally, B2B service sector studies have not taken into account the relationship between customers and service providers (White and Yanamandram, 2007). This study aims to fill the aforementioned gaps in the relevant literature and present the most common service failures experienced by third party logistics service providers, most common recovery strategies of third party logistics service providers and the effects of these recovery strategies on B2B relationships between third party logistics service providers and their customers. The categorization of variables depending on the unique environment of third party logistics service providers is also presented.

Our research question focuses on the identification of $3 \mathrm{PL}$ service failures and our research objectives are to: (1) explore and analyze the most common service failures, (2) implemented recovery strategies in third party logistics service industry in Turkey and (3) investigate their impact on the related business relationships.

The purpose of this research is to determine the impact of service failure type, magnitude and frequency on the future relationship between $3 \mathrm{PLs}$ and their customers, identify the implemented service recovery strategy, whilst underscoring the differences between possible options and offer guidelines for 3PL professionals aimed at ensuring high customer satisfaction through efficient service failure and recovery management. The paper then explains the research methodology used, manner of data collection, reliability, data analysis and results, offers a conclusion, gives recommendations and ends with limitations and further research sections.

\section{REVIEW OF LITERATURE ON SERVICE FAILURE AND RECOVERY STRATEGIES}

Service failure management is mainly complicated due to the simultaneity of production and consumption (Michel, 2001) and the challenge of satisfactory recovery. The first implies that, when service failures actually occur, the presence and the involvement of customers in service production makes it almost impossible to recover from the failure without letting customers know something has gone wrong. Moreover, considering the high level of human involvement in many services and the simultaneity of production and consumption, the occurrence of service failures is also almost unavoidable (Boshoff and Leong,1998). It must be noted that both B2C and B2B have similar customer expectations and perceptions, implying that from the customer's point of view, the failure is still a result of a decision made by an individual (Chou et al.,2009). However, from the perspective of B2B services, critical incidents like service failures have greater impact since they usually have major economic consequences due to the multiplying effect (van Doorn and Verhoef, 2008). Moreover, B2B service failures have an amplified effect when compared to consumer markets (Hübner et al., 2018)

\subsection{Failure Types}

When the service provided fails to meet customer expectations, a service failure occurs (Halbheer et al., 2018). There are two different major types of failure: outcome failure (Grönroos, 1988; Parasuraman et al., 1991; Keaveney, 1995; Smith et al., 1999; Levesque and McDougall, 2000; Michel, 2001; Swanson and Hsu, 2009) and process failure (Grönroos, 1988; Parasuraman et al., 1991; Keaveney, 1995; Smith et al., 1999; Michel, 2001; Johnston and Michel, 2008). Outcome failure is when the customer does not receive the service paid for, whereas process failure refers to a disruption in the provision of the aforementioned service (Smith et al., 1999). The occurrence of an outcome failure is worse for the company since it is a core failure more likely to result in losing the customer than process failure. Outcome failure motivates the service provider to put more effort into recovery than process failure (Chou et al., 2009; Bitner et al., 1990; Hoffman et al., 1995; Keaveney, 1995; Mohr\&Bitner, 1995; Grönroos, 1988; Parasuraman et al. 1985; Smith et al.,1999). In addition, it was highlighted "that service failure severity has a substantial adverse effect on consumer repurchasing behaviour" (Rai \& Ozuem, 2019). The service failure severity denotes the intensity of the problem as perceived by the customer (Reis et al., 2019). And finally, the involvement of a third-party logistics (3PL) company in this failure situation is expected to cause significant change in customer responses. As high quality logistics services are means of company differentiation, failure to provide services of requisite quality is expensive for all partners in the supply chain, which is why literature on service failures should pay more attention to collaborative efforts than to single company situations (Oflaç et al., 2012). The most common service failures in the forwarding industry are related to documentation, information and communication, operations, equipment, booking and delivery services (Gidener Özaydın et al., 2015). Although reducing the failure rate to zero is optimal and cost beneficial, it is only valid when the benefit to be gained outweighs the costs of achieving a fail-safe service (Halbheer et al., 2018). In this case the importance of service recovery must be underlined. 


\subsection{Service Recovery}

The significance of logistics service failure recovery is repeatedly emphasized (Andrejić \& Kilibarda, 2017). As consumer habits have changed, they no longer quietly accept low quality services or failures in the highly competitive service environment, forcing service providers to develop contingency plans in case of failure (Migacz \& Petrick, 2018).

Service recovery is basically the service provider's response to a service failure (Grönroos, 1988; Weun et al., 2004). It is the process whereby the satisfaction of the aggrieved customers with the company is regained, after a service has failed their expectations (Zemke and Bell, 1990). The importance of service recovery for post-failure customer satisfaction is well established (Bitner et al., 1990; Smith et al., 1999; Tax et al., 1998, Keaveney, 1995). Since service failures and failed recoveries are the foremost reason behind customers switching to other service providers (Keaveney, 1995), the importance of the issue becomes apparent. Besides, service recovery is crucial in the sense that satisfaction is a significant determinant of key outcome variables such as trust, commitment, word-of- mouth and long-term relationship (Bitner et al., 1990; Hart et al., 1990; Michel, 2001; Weun et al., 2004; Ok et al.,2005). Service recovery is both a means to enhance customer satisfaction at the transaction-specific level and a relationship tool; hence it is extremely important and plays a unique role in the service sector (Brown et al., 1996). Service recovery is significant since, poor customer retention has financial implications. Furthermore, financial implications of poor customer retention increase over time (Brinsmead,2007; Johnston and Michel,2008). Customer retention and loyalty are of crucial importance for service providers and the most effective way to ensure that loyalty is to provide a service that meets or exceeds the customer's expectations every single time. However, service delivery and its unique characteristics make it, at times, impossible to provide without fail. Even though service failure can be detrimental to loyalty, effective recovery may be sufficient for the customer to remain or even become more loyal than hey have previously been (Miller et al., 2000).

In addition, customers expect different recoveries depending on the severity of the experienced service failure and the recovery should match the service failure at hand (Smith et al., 1999; Levesque and McDougall, 2000; Craighead et al., 2004; Bradley and Sparks, 2012). When a service failure occurs, the level of recovery required to restore confidence depends on the magnitude of the failure. The severity of service failure also has a direct influence on the required recovery (Levesque and McDougall, 2000). Moreover, the smaller the magnitude of the service failure the greater the chance that recovery will have a positive impact on the customer's opinion (Smith et al.,1999). Consequently, service failures can be concluded to influence both the required recovery strategy to be implemented and the effectiveness of such recovery.
We must accept the fact that failures are undesirable yet inevitable, that whenever a failure occurs the speed and the way companies recover influence customer responses immensely (Swanson and Hsu, 2009; Smith et al., 1999; Chou et al., 2009) and that the company's response has the potential to either restore customer satisfaction and reinforce loyalty or aggravate the situation and cause it to lose the customer (Smith et al., 1999). The recovery chosen should be commensurate with service failure and meet customer expectations to avoid any mismatches and lost opportunities for customer satisfaction, loyalty and retention (Craighead et al., 2004). Service failure management should be an integral part of customer service rather than a reactive ad hoc process (Brinsmead, 2007). Recovery from service failure is an indelible part of the service provided, of utmost importance for maintaining excellence, a fundamental asset of the company and an opportunity to restore or even improve the relationship between the service provider and the customer (Flores and Primo, 2008; Hart et al., 1990; Swanson and Hsu, 2009; Ok et al., 2005). Whenever a recovery is well-managed, it provides additional capabilities, strengthens personal relations and increases confidence in the service provider, which is highly significant on B2B markets that 3PLs operate in (Hübner et al., 2018).

\subsubsection{Recovery Time}

Apart from choosing a recovery commensurate with its failure counterpart, the response time of the service provider company also plays an important role in post-failure outcome. A recent study on recovery dimensions has shown that in customers' eyes the speed of recovery is the first item on the agenda in the recovery context (Battaglia et al., 2012). As pointed out, the shorter it takes to address the issue at hand, the lesser the damage to customer satisfaction and loyalty (Craighead et al., 2004; Hart, et al., 1990). Likewise, it was stressed that speedy response was more likely to influence customers' justice evaluations when the experienced service failure was less severe (Smith et al., 1999; Battaglia et al., 2012).

The impact of the inability to provide services on time and delays in service recovery is evident in literature (Hart et al., 1990; Spreng et al., 1995; Tax et al., 1998; Zemke\& Bell, 1990; Taylor and Baker, 1994; del Rio- Lanza et al., 2009; Battaglia et al., 2012). Short recovery response time refers to the ability to contain the problem quickly and thus restore the customer's piece of mind, since failures have a detrimental effect on customer's operations (Battaglia et al., 2012). Likewise, considering the importance of timeliness for the quality of the physical distribution service (Bienstock et al., 1996), it is clear that shorter recovery times will result in better outcomes for the service provider. Therefore, the sooner recovery takes place, the higher the level of anticipated customer satisfaction after service recovery 
(Boshoff,1997). Moreover, the importance of identifying failures and implementing recoveries in the shortest period possible has been stressed in both B2C and B2B contexts (Bell and Zemke, 1987; Boshoff, 1999; Miller et al., 2000; Craighead et al., 2004).

\subsubsection{Recovery Types}

Literature identifies three recovery types: symbolic recovery (Bagozzi, 1975; Bell and Zemke, 1987; Bitner et al., 1990; Brown et al., 1996; Boshoff, 1997; Boshoff and Leong, 1998; Smith et al., 1999; Miller et al., 2000; Boshoff, 1999; Levesque and McDougall, 2000; Zhu et al., 2004; Johnston and Michel, 2008; Swanson and Hsu, 2009; Bradley and Sparks, 2012), utilitarian recovery (Bagozzi, 1975; Bitner et al., 1990; Brown et al., 1996; Boshoff, 1997; Boshoff and Leong, 1998; Smith et al., 1999; Miller et al., 2000; Boshoff, 1999; Levesque and McDougall, 2000; Zhu et al., 2004; Johnston and Michel, 2008; Swanson and Hsu, 2009; Bradley and Sparks, 2012) and mixed recovery (Boshoff, 1997; Boshoff and Leong, 1998; Miller et al., 2000; Levesque and McDougall, 2000; Swanson and Hsu, 2009). Symbolic service recovery is recovery that does not have an economic outcome for the customer. Symbolic service recovery includes symbolic exchange such as an apology. However, it needs to be emphasized that process service failures require symbolic service recovery since it is commensurate with the service failure experienced (Smith et al., 1999). Another approach also calls symbolic service recovery process recovery (Zhu et al.,2004). Utilitarian service recovery has an economic outcome for the customer after service failure, in the form of compensation, discount etc. Utilitarian service recovery is required in case of outcome (core) service failure. Since outcome service failure results in economic loss for the customer, recovery which involves economic gain is required to restore balance to the relationship (Smith et al., 1999). As mentioned above, another approach considers utilitarian service recovery outcome recovery commensurate with its failure counterpart (Zhu et al., 2004). Mixed service recovery means the application of two or more of the above mentioned service recoveries, e.g. a combination of one symbolic and one utilitarian or two symbolic and one utilitarian recovery, etc. The main point is that both recovery types are simultaneously applied within a single recovery effort and the choice depends on the type of the service failure at hand (Chou et al.,2009). Customer perception of the buyer-seller relationship with the service provider has an immense impact on their recovery strategy expectations, which may shed a light on why some customers are satisfied, while others are not after a similar recovery following failure. If service provider considers his relationship with the customer good, he is willing to put more effort into maintaining it and hence in the recovery attempt. Service recovery effort is perceived as high if a "mixed recovery strategy" is used. Mixed recovery strategy could consist of a combination of utilitarian strategy (discount, compensation, expense share) and an additional symbolic strategy (apology, assistance, correction) (Chou et al.,2009). The four proposed outcomes of service failures and subsequent recovery are improved relationships, weakened relationships, adjourned relationships and relationships that are not influenced by the service failure and recovery (Edvardsson, 1992).

\section{RESEARCH METHODOLOGY: CRITICAL INCIDENT TECHNIQUE (CIT)}

The Critical Incident Technique (CIT) was first brought to attention in 1954 in the Psychological Bulletin by Flanagan.

"The critical incident technique consists of a set of procedures for collecting direct observations of human behavior in such a way as to facilitate their potential usefulness in solving practical problems and developing broad psychological principles".

This technique provides steps for collecting observed incidents with "high significance and meeting systematically defined criteria". These "criteria" are defined as "any observable human activity that is sufficiently complete in itself to permit interferences and predictions to be made about the person performing the act", besides, for an incident to be "critical" it "must occur in a situation where the purpose or intent of the act seems fairly clear to the observer and where its consequences are sufficiently definite to leave little doubt concerning its effects" (Flanagan, 1954). Furthermore, critical incidents are "special, problematic, sensitive or directly unpleasant" and "can arise anywhere" and "occur even in the best of companies" (Edvardsson,1998). There are no strict data collection rules, as any rules have to be modified and adjusted to the specific situation at hand.

The advantages of the CIT are: respondents' perspective is described in their own words (Edvardsson,1992), it reflects the normal way service customers think (Stauss,1993), obtainment of unequivocal and very concrete information (Stauss and Weinlich, 1997), increased knowledge, usefulness for explaining or describing a phenomenon (Bitner et al.,1990), flexible set of rules (Flanagan, 1954, Gremler, 2004), possibility of interaction between all possible components (Koelemeijler,1995), no need for hypothesis and room for developing concepts and theories (Olsen and Thomasson,1992), accurate and indepth record of events (Grove and Fisk,1997), rich set of data (Gabbott\&Hogg,1996), more in-depth and detailed data than in typical customer satisfaction research (Bitner et al.,1994), easy adaptation to understand the experiences of others (Burns et al., 2000), powerful and vivid insight into a phenomenon (Zeithaml \& Bitner, 2003) and suggests practical areas of improvement to managers (Stauss, 1993: Odekerken-Schröder et al. 2000).

Although the benefits of the CIT method are considerable, it has also received some criticism from scholars. Drawbacks and limitations of the CIT are: its reliability and validity (Chell, 
2004), possible misinterpretation or misunderstanding of the stories (Edvardsson, 1992), design that may be flawed by recall bias (Michel, 2001), bias through consistency factors or memory lapses (Singh and Wilkes, 1996), possible low response rate due to respondents not being familiar with or not wanting to spend time to tell a complete story when describing the critical incident (Edvardsson and Ross 2001, Johnston,1995), problems may also arise as result of ambiguity associated with category labels and coding rules within a particular study (Weber1985)

However, the advantages outweigh possible drawbacks of the method, and the importance of the CIT method in service research is undeniable, as the technique has become a tool for reflecting customer perceptions of quality and customer satisfaction (Edvardsson and Roos, 2001). CIT may reveal a new dimension of service failures in the B2B context or contribute to the existing ones (Lockshin \& McDougall, 1998). Moreover, the second most popular research topic in CIT studies is service failure and recovery (Gremler, 2004; Craighead et al., 2004). Recent applications of CIT in service literature include (Bitner et al., 1990, Hoffman et al., 1995; Edvardsson, 1998; Johnston, 1995; Youngdahl and Kellogg, 1997; Lockshin \& McDougall,1998; Dasu and Rao, 1999; Swanson and Hsu, 2009; Miller et al., 2000 and Craighead et al., 2004; Chung-Herrera et al., 2004; Kelley et al., 1993; Keaveney, 1995; Lewis \& Spyrakopoulos, 2001; Reynolds \& Harris, 2005).

\subsection{Sampling and Data Collection}

The data collection tool was developed in the pretesting phase. Initially, 20 in-depth interviews (10 with third party logistics service providers and 10 with customers) were conducted with third party logistics service providers and their customers between August 06-14, 2015, in which CIT was used to identify service failures and recovery strategies. Information on a total of 38 service failure and recovery incidents were collected by means of personal interviews with third party logistics company managers and information on a total of 36 service failure incidents from export and import companies. The data obtained were used in the pre-testing phase of the study.

The average duration of in-depth interviews was approximately 60 minutes, depending on the number of incidents shared by the managers. During the in-depth interviews, each respondent recounted a personal experience of an entire episode of service failure, mistake or problem, actions taken by customers and recovery actions of the service provider in the third party logistics industry. The measuring scale was a likert type 2 - item 10-point scale with anchors of "1" (min) to "10" (max) (Caceres and Paparoidamis, 2005; Swanson and Hsu, 2009).

This study took into account both the customers' and the service providers' points of view in the analysis of service failures and recovery strategies, since B2B service encounters are dyadic
(Solomon et al., 1985). The population of the study are export and import companies (also called shippers in the logistics industry) as customers and third party logistics service providers in Turkey. In order to capture service providers' point of view on service failures and recovery strategies in third party logistics services, managers or employees of third party logistics service provider companies were also included in the research. A list of 406 third party logistics companies in Turkey obtained from the Association of International Forwarding and Logistics Service Providers (UTIKAD) was examined in detail. Though the authors attempted to reach all the companies, they were forced to reduce the sample to 235 third party logistics companies located in Turkey due to the non-availability of contact information. A total of 110 service failure incidents have been collected from 70 (29.7 $\%$ ) third party logistics companies located in Turkey. In this study, both the personal interview and the survey questionnaire were structured around the model of cause, course and result of the incident (service failures and recoveries) being reported. This model is especially widely used in research on negative critical incidents such as service failures (Edvardsson, 1992, Edvardsson, 1998; Bejou and Palmer, 1998; Bejou et at., 1996).

The convenience sampling process was used to select the sample from the population of customer companies. A total of 150 questionnaires were e-mailed to the customers of service providers. Information on a total of 115 service failure and recovery incidents have been obtained from 81 (54\%) export and import companies using third party logistics services. Critical incidents related to service failures and recoveries have been collected from the managers or employees of logistics departments of customer companies.

\subsubsection{Reliability}

Reliability is a key component in analytical methods due to the possible effect of subjectivity. In CIT studies employing content analytic methods, reliability assessment usually focuses on the judge's ability to consistently classify incidents into the same categories. The most commonly reported statistic relating to the reliability of CIT studies is the percentage of agreement. In this kind of research, reliability could include discussion on both intrajudge and interjudge reliability, however, in this study, intrajudge reliability concerned with the consistency of a judge's categorization decisions over time (Weber, 1985) was employed. Interjudge reliability is defined as "the degree to which two or more judges agree that a given observation should be classified in a particular way" (Perrault and Leigh, 1989). Reliability is assessed by means of reliability indices used and the size of statistics reported. The purpose of reliability indices is to verify the likelihood that various judges would have classified given critical incidents in a similar way. 
The author and an academician who has a background in the logistics industry independently classified all the service failures collected both from the customer companies and third party logistics provider companies. The differences and discrepancies in the classifications were identified, discussed and resolved by the coders. In this study, interjudge agreement on the classification of service failure incidents was $85 \%$ for customer companies and $90 \%$ for third party logistics service provider companies.

\section{DATA ANALYSIS}

Each third party logistics company was requested to have employees from three different departments, including Marketing and Sales, Operations and Documentation, and Accounting, to fill out the questionnaire form. A total of 110 service failure and recovery incidents were collected from third party logistics companies. Two of these incidents were excluded from analysis since the data did not meet the critical incident criteria defined in the study. A total of 115 service failure and recovery incidents were collected from customer companies by email and internet survey. Seven incidents collected from customer companies were excluded due to missing critical information and inability to meet the critical incident criteria defined in the study.

The number of incidents that are or should be included in CIT is always open for debate. Flanagan (1954) recommends that "no new incidents should appear in the last 100" collected incidents. A total of 225 service failure incidents have been collected via e-mail in a four-month period between September and December 2015. As mentioned above, nine incidents were excluded and 216 service failure incidents included in the analysis; 108 service failure incidents from shipping companies and 108 service failure incidents from 3PL's. As this study is conducted in a B2B setting and context, the total number of incidents collected from shippers and 3PL's was deemed satisfactory.

The aforementioned gaps in the B2B service failure and recovery research, such as: the aftermath of service failures in 3PL services, studies including both satisfied and dissatisfied customers after recovery and the relationship between customers and service providers, have not been taken into account in the B2B service sector. Edvardsson's (1992) cause, course and result approach was adapted to this study, with the addition of new variables highlighted in the service failure and recovery literature and the apriori model was proposed.

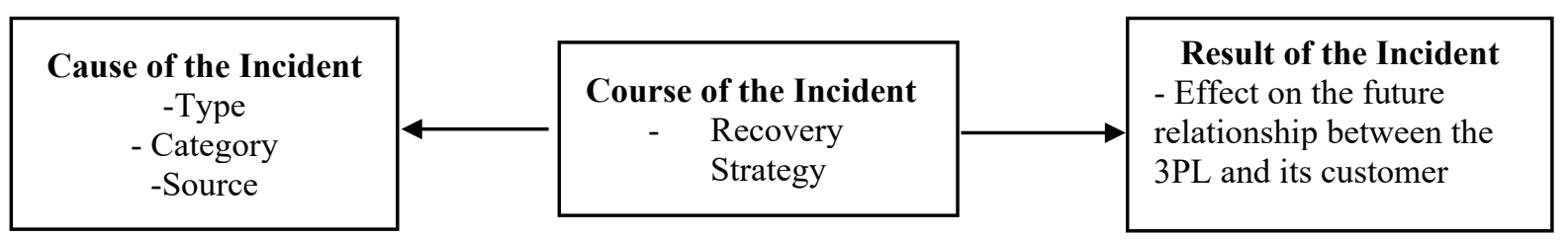

Figure 1.

Analytical Model of Research.

The first stage of critical incident analysis in this study consisted of inductive delineation of major groups that could collectively account for all the incidents and finding general answers to main research purposes and questions. In order to establish the initial classification scheme, the author and an academician reviewed a sample of service failure incidents in third part logistics services.

The analysis began with the careful scrutiny of service failure incidents collected from customer companies and third party logistics service providers. In the study, the author and an academician, acting independently from each other, classified service failures and recovery strategies into a number of categories. Two successive clustering processes conducted by two coders resulted in major categories. Having reached a consensus on the main categories, the process of category delineation within the groups was initiated. Using an iterative process, two coders read, sorted, reread and combined service failure incidents on category labels. Service failure incidents were classified into main categories and subcategories. The examples of service failure categories from both perspectives are presented. In addition to classifying critical incidents by source and nature of service failures, they were also classified by the magnitude of the mistake as perceived by the respondent. The course of service failure incidents/service recovery strategies was also classified into main categories and subcategories. Finally, the results of service failures and recovery strategies were included in the study. 


\subsection{Cause of the Incident}

The first part of the model includes types, categories and sources of failures from both perspectives. The second part includes recovery strategies from both perspectives and the last part presents the impact of the incident on the relationship between 3PLs and their customers. Table 1 clearly shows that the majority of incidents shared by respondents are outcome failures, which was to be expected due to the complexity and time sensitivity of the logistics activities.

Table 1.

Failure Types: Customer Perspective vs. 3PL Perspective.

\section{Customers}

\section{Logistics Service Providers}

\begin{tabular}{llllll}
\hline Failure Types & Count(N) & Per. ( \%) & Count(N) & Per. ( \%) & Total \\
\hline Process & 15 & 13,9 & 47 & 43,5 & 62 \\
\hline Outcome & 93 & 86,1 & 61 & 56,5 & 154 \\
\hline Total & $\mathbf{1 0 8}$ & $\mathbf{1 0 0}$ & $\mathbf{1 0 8}$ & $\mathbf{1 0 0}$ & $\mathbf{2 1 6}$ \\
\hline
\end{tabular}

Table 2. shows failure categorization from the customer perspective. The majority of failures are customer service and operations failures. The second most common failure shared by customers pertains to port operations. These failures are failures with the highest magnitude and frequency. The highest recovery satisfaction is associated with customer service and operations failures which are also the quickest recoveries. Incidents regarding marketing/ sales and finance/accounting failures have the longest recovery response time.

Table 2.

Failure Categories: Customer Perspective.

\begin{tabular}{|c|c|c|c|c|c|c|c|}
\hline Failure Categories & Count (N) & Per. (\%) & $\begin{array}{l}\text { Cum. Per. } \\
(\%)\end{array}$ & Fail. Magn.* & Fail.Freq.** & $\begin{array}{l}\text { Recov. } \\
\text { Satis.*** }\end{array}$ & $\begin{array}{l}\text { Recov. } \\
\text { Respon.***** }\end{array}$ \\
\hline $\begin{array}{l}\text { Customer Service/ } \\
\text { Operation }\end{array}$ & 67 & 62 & 62 & 7.22 & 5.98 & 5.53 & 5.29 \\
\hline Documentation & 12 & 11.1 & 73.1 & 7.16 & 4.91 & 2.83 & 6.08 \\
\hline Finance/ Accounting & 5 & 4.6 & 77.8 & 7.4 & 2.8 & 4.4 & 7 \\
\hline Marketing/ Sales & 3 & 2.8 & 80.6 & 8.3 & 3 & 1.6 & 10 \\
\hline Port Operations & 21 & 19.4 & 100 & 7.85 & 6.8 & 4.23 & 6.14 \\
\hline Total & 108 & 100 & & & & & \\
\hline $\begin{array}{l}* 1=\text { minor } \\
* * 1=\text { very frequent } \\
* * * 1=\text { very dissatisfied } \\
* * * * 1=\text { very quick }\end{array}$ & \multicolumn{2}{|c|}{$\begin{array}{l}10=\text { major } \\
10=\text { very rare } \\
10=\text { very satisfied } \\
10=\text { very slow }\end{array}$} & & & & & \\
\hline
\end{tabular}

Table 3, which presents failure categorization from both the customer and the 3PL perspective, reveals that the most common failures are customer service and operations related failures, followed by port operations failures. The longest recovery response time is again associated with marketing and sales related failures. As the slowest recovery was rated 5 by 3PLs, whereas the fastest recovery was rated 5.29 by the customers, there is clearly a discrepancy between recovery responsiveness perceptions of the two parties. The customers perceive the recovery as slower and are not as satisfied as 3PLs think (see Table 4). Though recovery satisfaction levels are much higher in 3PL perception, both parties have a similar perception of failure magnitude. 
Table 3.

Failure Categories: 3PL Perspective.

\begin{tabular}{|c|c|c|c|c|c|c|c|}
\hline $\begin{array}{l}\text { Failure } \\
\text { Categories }\end{array}$ & Count (N) & Per. (\%) & $\begin{array}{l}\text { Cum. Per. } \\
(\%)\end{array}$ & Fail. Magn.* & Fail. Freq.** & $\begin{array}{l}\text { Recov. } \\
\text { Satis.*** }\end{array}$ & $\begin{array}{l}\text { Recov. } \\
\text { Respon.**** }\end{array}$ \\
\hline $\begin{array}{l}\text { Customer Service } \\
\text { / Operation }\end{array}$ & 52 & 48.1 & 48.1 & 7.34 & 6.46 & 7.44 & 4.26 \\
\hline Documentation & 17 & 15.7 & 15.7 & 7.88 & 6.35 & 7 & 4.47 \\
\hline $\begin{array}{l}\text { Finance/ } \\
\text { Accounting }\end{array}$ & 7 & 6.5 & 70.4 & 8 & 5.42 & 8.42 & 3.85 \\
\hline Marketing/ Sales & 7 & 6.5 & 76.9 & 8 & 3.5 & 6.57 & 5 \\
\hline Port Operations & 25 & 23.1 & 100 & 7.2 & 4.96 & 7.44 & 3.88 \\
\hline Total & 108 & 100 & & & & & \\
\hline $\begin{array}{l}* 1=\text { minor } \\
* * 1=\text { very frequent } \\
* * * 1=\text { very dissatisfied } \\
* * * 1=\text { very quick }\end{array}$ & \multicolumn{2}{|c|}{$\begin{array}{l}10=\text { major } \\
10=\text { very rare } \\
10=\text { very satisfied } \\
10=\text { very slow }\end{array}$} & & & & & \\
\hline
\end{tabular}

Table 4.

Failure Source Classifications: Customer Perspective vs. 3PL Perspective.

Customer Perspective

\begin{tabular}{lllllllll}
\hline Failure Source & Count (N) & Per. ( \%) & Cum. Per. ( \%) & Failure Source & Count (N) & Per. ( \%) & Cum. Per. ( \%) \\
\hline Railway Operator & 0 & 0 & 0 & Railway Operator & 1 & 0.9 & 0.9 \\
\hline Lashing Company & 0 & 0 & 0 & Lashing Company & 1 & 0.9 & 1.8 \\
\hline Carrier & 32 & 29.6 & 29.6 & Carrier & 33 & 30.6 & 32.4 \\
\hline Customer & 1 & 0.9 & 30.6 & Customer & 31 & 28.7 & 61.1 \\
\hline Customs Broker & 1 & 0.9 & 31.5 & Customs Broker & 1 & 0.9 & 62.0 \\
\hline Government Bodies & 1 & 0.9 & 32.4 & Government Bodies & 1 & 0.9 & 62.9 \\
\hline Haulier & 5 & 4.6 & 37.0 & Haulier & 5 & 4.6 & 67.6 \\
\hline 3PL & 62 & 57.4 & 94.4 & 3 PL & 20 & 18.5 & 86.1 \\
\hline Network Member & 1 & 0.9 & 95.4 & Network Member & 8 & 7.4 & 93.5 \\
\hline Port & 2 & 1.9 & 97.2 & Port & 4 & 3.7 & 97.2 \\
\hline Warehouse Operator & 3 & 2.8 & 100.0 & Warehouse Operator & 3 & 2.8 & 100.0 \\
\hline Total & $\mathbf{1 0 8}$ & & & Total & $\mathbf{1 0 8}$ & $\mathbf{1 0 0}$ &
\end{tabular}

\subsection{Course of the Incident}

The course of the incident is the recovery strategy implemented by the 3PL as a reaction to a service failure. From both perspectives, the most commonly implemented recovery strategies are symbolic recovery strategies (see Table 5). These recovery strategies include apology, assistance and correction activities undertaken by service providers. From the customers' perspective, the second most common course is no recovery, whereas $3 \mathrm{PL}$ perspective suggests that utilitarian recovery strategies are the second. Nonetheless, in a total of 40 incidents, both the customers and 3PLs agree that there was no recovery. 
Table 5.

Recovery Classification: Customer Perspective vs. 3PL Perspective.

Customer Perspective

\begin{tabular}{llllllll}
$\begin{array}{l}\text { Recovery } \\
\text { Classification }\end{array}$ & Frequency & Per. (\%) & $\begin{array}{l}\text { Cum. Per. } \\
(\boldsymbol{\%})\end{array}$ & $\begin{array}{l}\text { Recovery } \\
\text { Classification }\end{array}$ & Frequency & Per. (\%) & $\begin{array}{l}\text { Cum. Per. } \\
\text { (\%) }\end{array}$ \\
\hline Mixed & 12 & 11.1 & 11.1 & Mixed & 10 & 9.3 & 9.3 \\
\hline No recovery & 26 & 24.1 & 35.2 & No recovery & 14 & 13.00 & 22.2 \\
\hline Symbolic & 51 & 47.2 & 82.4 & Symbolic & 56 & 51.9 & 74.1 \\
\hline Utilitarian & 19 & 17.6 & 100 & Utilitarian & 28 & 25.9 & 100 \\
\hline Total & $\mathbf{1 0 8}$ & $\mathbf{1 0 0}$ & & Total & $\mathbf{1 0 8}$ & $\mathbf{1 0 0}$ &
\end{tabular}

\subsection{Result of the Incident}

As previously mentioned, the result of the incident is the effect of failure and recovery on the relationship between 3PLs and their customers. The relationship categories are based on Edvardsson's (1992) study and are as follows: not influenced, adjourned, improved and weakened (see Table 6). Both parties hold that the majority of relationships are not influenced by service failure and recovery. However, customers' perspective indicates adjourned relationships as the second largest group, whereas 3PL's perspective suggests that improved relationships are the second largest group. The difference could perhaps also be related to the different perceptions of failure magnitude, frequency and recovery satisfaction level by the two parties.

Table 6.

Relationship after Service Failure and Recovery: Customer Perspective vs. 3PL Perspective.

Customer Perspective

3PL Perspective

\begin{tabular}{|c|c|c|c|c|c|c|c|}
\hline $\begin{array}{l}\text { Relationship } \\
\text { with 3PL }\end{array}$ & Frequency & Per. ( \%) & Cum. Per. ( \%) & $\begin{array}{l}\text { Relationship } \\
\text { with customer }\end{array}$ & Frequency & Per. (\%) & $\begin{array}{l}\text { Cum. Per. } \\
(\%)\end{array}$ \\
\hline Not influenced & 48 & 44.4 & 44.4 & Not influenced & 58 & 53.7 & 53.7 \\
\hline Adjourned & 25 & 23.1 & 67.6 & Adjourned & 6 & 5.6 & 59.3 \\
\hline Improved & 3 & 2.8 & 70.4 & Improved & 25 & 23.1 & 82.4 \\
\hline Weakened & 32 & 29.6 & 100 & Weakened & 19 & 17.6 & 100 \\
\hline Total & 108 & 100 & & Total & 108 & 100 & \\
\hline
\end{tabular}

\section{DISCUSSION}

This research examined service failures and recovery strategies implemented by 3PL's in the logistics services from both the customers' and 3PLs' perspectives. Service failures and recovery strategies were analyzed using CIT. Although CIT has been widely used in consumer markets, there are only limited examples of its use in the field of B2B services. This study therefore fills the gap in the relevant literature. CIT was also found to be useful in the analysis of service failures and recovery strategies in the $B 2 B$ services setting.

Literature shows that consumer markets have relatively more relational failures, whereas B2B failures are mostly output failures since the focus is on the result. After data collection through CIT and analysis, failure types were categorized from the customers' point of view. Outcome failures account for $86.1 \%$ (93) and process failures for $13.8 \%$ (15). This is mostly due to the time sensitivity of logistics services and the likelihood that the customers will remember the worst of the worst. From the 3PL perspective, process failures account for 43,5\% (47) and outcome failures for $56,5 \%$ (61). There are more process failures from the 3PL perspective; this may be due to the fact that these failures are perceived as less important or that 3PLs' total awareness of the process is greater than the customers'. Even though in service settings customers are involved in the service provision process, they may not be fully aware of all the details. Hence, 
unlike the literature suggests, 3PL service providers may conceal failures from the customers if they manage to fix them before the customers become aware of their existence.

CIT also provided sufficient information for the classification of failure categories. Likewise, Durvasula et al., (2000) examining maritime transport recovery strategies and customer satisfaction, also found CIT a useful method for effective service development in B2B services. Whereas past research mostly focused on the customers' side of the service failures, rarely taking into account the service providers', this study took the dyadic approach, taking into account both the customers' and the 3PLs' perspectives to get the whole picture and increase the reliability and validity of B2B services. The aforementioned failure categories are customer service and operation, documentation, finance and accounting, marketing and sales and port operations. The most frequently observed failure categories from both perspectives are: customer service and operations, port operations and documentation, owing to the nature of the logistics services provided by 3PLs. The majority of services provided by 3PLs include customer interaction and there are a multitude of documents and port operations involved, including loading, transfer, carrier activities, transit times etc.

From both perspectives, service failures with the highest magnitude are associated with marketing and sales, finance and accounting. Therefore, 3PLs must be aware of the importance of these departments and related activities, since any disruption is perceived by customers as highly important. The lowest levels of satisfaction after recovery are likewise associated with marketing and sales failures from both perspectives.

On the recovery side, the most common recovery strategy from both perspectives is symbolic recovery. This is probably due to its simplicity. Symbolic recovery includes apology, correction and assistance. These include apologizing to the customers for service failures, trying to get extra time for loading from the carrier, arranging extra air cargo to outweigh the negative outcomes of delay etc. However, the analysis showed no evidence that recovery strategies affected the relationship between 3PLs and their customers after service failure and recovery, but suggest that they affected recovery satisfaction instead. Although from both perspectives the highest level of satisfaction after recovery is perceived in customer service and operation and finance and accounting failures, this may be due to the fact that these failures call for utilitarian recovery which is associated with higher customer satisfaction.

Recovery responsiveness should also be taken into account, as customer service and operations and documentation failures are perceived by customers to be dealt with the fastest, which may be why they resulted in the highest recovery satisfaction in line with the literature. Likewise, the slowest recovery in customers' perception was associated with marketing and sales and finance and accounting failures, though satisfaction levels here differ. As mentioned above, since finance and accounting failures require utilitarian recovery, recovery satisfaction is higher. However, symbolic recovery after marketing and sales failures is insufficient, since magnitudes are perceived to be the highest in these two domains. Consequently, the findings are compatible with the literature in the sense that, to satisfy customers, higher magnitude failures require utilitarian recovery.

In addition, the following sources of failures have been identified and categorized: railway operator, lashing company, carrier, customer, customs broker, government bodies, haulier, 3PLs, network members, ports, warehouse operators. The customers perceive carriers and 3PLs as the most common failure sources, whereas 3PLs focus on carriers, 3PLs and customers as failure sources. The absence of customers as a failure source from the customers' perspective may be due to the external attributions of the customers with respect to failures.

From both perspectives, relationships mostly remain unaffected after the failure and recovery process, which may be due to oligopolistic competition in this sector and the consequent lack of alternatives or to the importance of long lasting relationships for the ease of doing business. Two of the most important findings here are that customers indicated that $25(27 \%)$ incidents resulted in the termination of the relationship, whereas 3PLs only mentioned 6 (6.5\%). Moreover, according to $3 \mathrm{PLs}, 25$ (27\%) incidents resulted in improved relationship, whereas the customers only mentioned 3 (3.2\%). The reason behind this discrepancy may be the reluctance of 3PLs to share such information or the desire of customers to stress the importance of these incidents.

\section{RECOMMENDATIONS}

Most of the CIT research on services focuses on B2C services like banking, hospitality, restaurant, airline travel, retail and public transport, with special emphasis on encounters and interactions. However, this research analyzed third party logistics service failures and recoveries and contributed to the B2B service literature. Service failure classifications of $3 \mathrm{PL}$ services and $\mathrm{B} 2 \mathrm{C}$ services are similar in the sense that the timeliness of recovery is crucial. On the other hand, 3PL services differ from B2C services with respect to customer involvement, customer professionalism, focus on the end result and level of complexity due to the number of parties involved in logistics services. Focus on the end result and the level of professionalism of both parties in 3PL services could also explain why there are fewer process failures. These findings correspond to the findings of Lockshin and McDougall (1998) on wine retail sale, where service outcomes in industrial markets were generally outcome issues like delay or damage.

Whereas previous studies on consumer services focused on the impact of service providers' employees on customer satisfaction or dissatisfaction and provided an insight 
into that dimension of service failures and recovery, this study focuses on negative critical incidents that have an impact on customer satisfaction or dissatisfaction with all 3PL services, rather than focusing solely on service failures attributable to $3 \mathrm{PL}$ employees. These critical incidents have also been examined from the aspects of failure magnitude, failure frequency, recovery responsiveness and customer satisfaction. Although service literature suggests that distribution channels and service delivery are short, in its examination of 3PL service failures and recoveries this study takes into account many actors contributing to the service delivery process in 3PL services, such as hauliers, carriers, customs brokers, ports, logistics network members, warehouse operators, government bodies, etc., demonstrating that logistics services can be disrupted by parties other than the customer and the service provider and thus contributing to B2B service literature and 3PL literature.

The conclusion of the study is that the majority of $3 \mathrm{PL}$ service failures are caused by carriers. 3PLs should therefore be more careful in their selection and evaluation of carriers they work with and keep in mind that 3PLs are responsible to customers just as carriers are responsible to 3PLs.

CIT revealed that the majority of $3 \mathrm{PL}$ service failures can be attributed to customer services and operations and this is where 3PL employees are most involved. Therefore, 3PLs could use employee performance evaluations, employee training, employee and customer interaction monitoring and the enforcement of strict rules to maintain service quality, provide seamless, sustainable services to their customers and nurture their relationship in between.

Likewise, 3PLs should pay more attention to their complaint management and claim handling procedures to improve customer service quality and customer satisfaction. Effective complaint handling and analysis will also allow 3PLs to efficiently identify the most problematic areas and dimensions of service quality, and implement recoveries in a timely manner. Although shipping lines and their agents have complaint handling departments, 3PLs usually do not. The formation of such a department would be beneficial for service quality and customer satisfaction.

On the other hand, customers are encouraged to use supplier performance evaluation systems to evaluate the performance of 3PLs they work with. Customers could then use these systems to choose high quality service providers. Customers are also advised to renew their contract or change the 3PLs that do not provide services of the required quality.

Moreover, the utilization of advanced information technologies that enable seamless information exchange between parties with minimum human error will help prevent miscommunication and documentation related failures. Both 3PLs and shipping lines were found to be heavily investing in information and communication technologies in order to avoid or minimize such failures.

Furthermore, 3PLs should adopt a rather proactive approach to service recovery and form quality management and quality improvement systems within the organization. The causes of service failures must be identified using quality systems and the required improvements carried out. Likewise, employee attitudes towards customers and their job competency should be improved to guarantee high service quality and customer satisfaction.

Owing to their complexity, logistics service failures are unavoidable, especially those regarding damage and delay. Therefore, obtaining liability insurance for such failures can be an effective way for 3PLs to both recover from failures and gain customers' trust.

Moreover, the social relevance of this study is that the lower number of 3PL service failures will reduce negative environmental impact caused by recurring activities, reduce carbon footprint and the waste of vital human and monetary resources. Impact on the governments is also significant considering they are responsible for providing and maintaining infrastructure used in logistics services. If not complete elimination, then a decrease in the number of unwanted service failures will allow these resources to be put to other use and possibly increase the quality of life for the stakeholders involved and contribute to the overall sustainability of the logistics macro-system.

\section{FUTURE RESEARCH}

Due to the complexity of $3 \mathrm{PL}$ services, there are a great many actors contributing to the provision of third party logistics services, such as: ports, customs brokers, governmental bodies, hauliers, ocean carriers, railway operators, airlines and others, depending on the nature of the service. The perspectives of all these actors should be explored to evaluate the overall logistics service system and increase objectivity.

Besides, although this research is, in a way, dyadic, for the full effect of the actual perceptions of the customers and 3PLs to be captured, a strictly dyadic research is required. A strictly dyadic relationship can be achieved only if research focuses on a single 3PL and its customers, and a single failure. Even though this study explored both perspectives, it did not exactly focus on both sides involved in certain failures.

Future studies should also look into critical incidents and 3PLs' complaint handling documents. Sample could be bigger and comparison could be made with other countries due to differences in logistics infrastructures and cultures. In addition, the same techniques should be used in other B2B service sectors to generalize findings. 3PL service failures and recoveries could also be examined using experimental methods. 
Some of the limitations of other CIT studies are also applicable to this study, e.g. customers or 3PL employees could misunderstand some of the qualitative and quantitative questions in the questionnaire or experience memory lapses. However, the same could be said of any marketing research, especially qualitative ones.

Other limitations of this research are sample size and national scope. This study was conducted as a cross-sectional study and the constraints associated with cross-sectional data may be overcome by longitudinal studies on 3PL service failure and recovery. Considering the long-term nature of purchasing decisions in B2B environments, longitudinal studies may be carried out to gain a wider understanding of failures and recoveries in 3PL services.

Moreover, this study classified 3PL service failures according to the general departmentalization of 3PLs. Future studies could also consider classifications based on logistics service phase or process, to identify the phase in which the majority of service failures occur, and suggest areas of improvement to 3PLs. Finally, future research may look further into the impact of these failures on sustainability and resource management.

\section{APPENDIX A}

\section{Critical Incident Data Collection Form for Service Failures and Recovery Strategies in Logistics Services: Customer Perspective}

Critical Incident Technique focuses on analyzing the events that are categorized as out of the ordinary between suppliers and customers. The purpose of this research is to investigate the logistics service failures, the utilized recovery strategies and how these effect the relationship between 3PLs and their customers. The name and titles of the related parties will be handles confidentially and only used for academic purposes. Thank you for your participation.

I.

Please describe a critical incident you experienced with your the logistics service provider within the last year in detail. ( What did you say after the failure? What caused this failure to happen? How did your supplier react)

(a) Please rank the importance/ magnitude of this service failure with regard to the damage it caused. (1: minor;10 major)

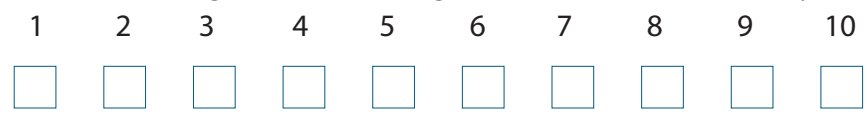

(b) Please specify how frequently you encounter this service failure (1: always; 10 : rarely)

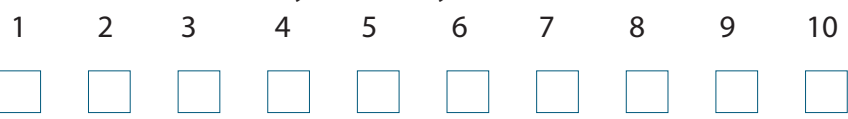

II.

(a). As the customer please explain in detail how the service provider handled the situation and what kind of actions were taken in order to recover from it.

(b). Please explain how you reacted against this incident in detail.

(c). Please rank how you evalute your satisfaction was regarding the way the failure was handled? (1: very weak; 10: very well)

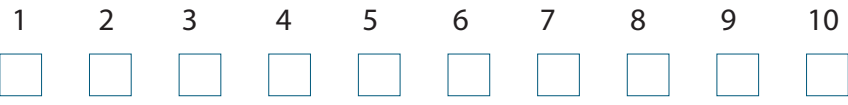

(d) How long did it take to recover (1: very short; 10: very long)

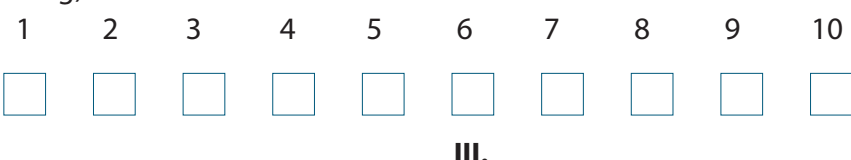

(a). How did this incident effect your business relationship with your service provider?

Adjourned Weakened Not Influenced Improved

(b). How did this incident effect your business relationship with your service provider?

Adjourned Weakened Not Influenced Improved

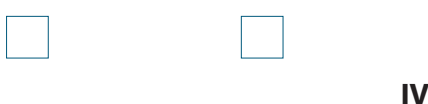

(a).Please specify this service provider's significance to your company with regard to transaction size. (1: not significant; 10:very significant)

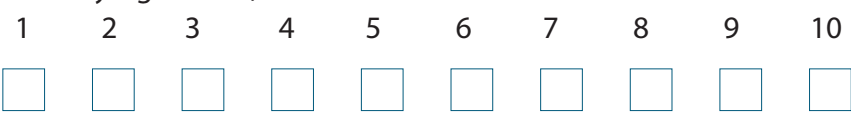

(b). How many years have you been working with this service provider?

less than $1 \quad 1-3 \quad 4-6 \quad 7-10 \quad$ more than 10 


\section{APPENDIX B}

\section{Critical Incident Data Collection Form for Service Failures and Recovery Strategies in Logistics Services: Logistics Service Providers' Perspective}

Critical Incident Technique focuses on analyzing the events that are categorized as out of the ordinary between suppliers and customers. The purpose of this research is to investigate the logistics service failures, the utilized recovery strategies and how these effect the relationship between 3PLs and their customers. The name and titles of the related parties will be handles confidentially and only used for academic purposes. Thank you for your participation.

\section{I.}

Please describe a critical incident you experienced with your customer as the logistics service provider within the last year in detail. ( What did you say after the failure? What caused this failure to happen? How did your supplier react)

(a) Please rank the importance/ magnitude of this service failure with regard to the damage it caused. (1: minor;10 major)

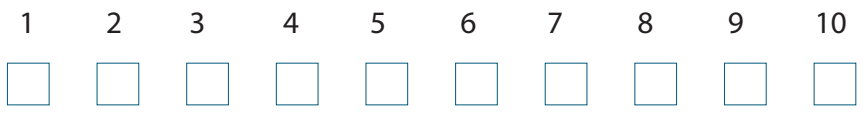

(b) Please specify how frequently you encounter this service failure (1: always; 10 : rarely)

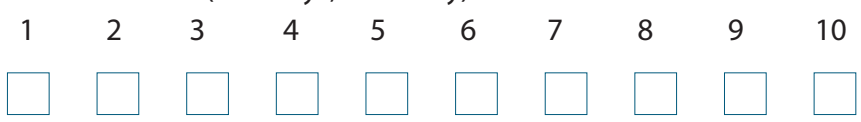

II.

(a). As the logistics service provider please explain in detail how you handled the situation and what kind of actions were taken in order to recover from it.

(b). Please explain how your customer reacted in detail.

(c). Please rank how you evalute your customers satisfaction was regarding the way the failure was handled? (1: very weak; 10 : very well)

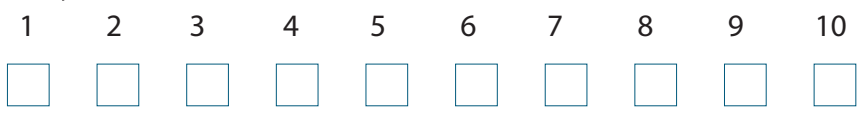
long)

(d) How long did it take to recover (1: very short; 10: very

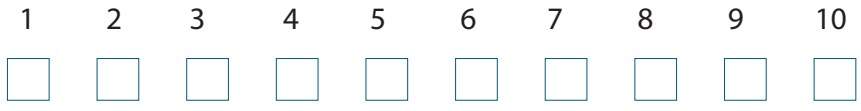

III.

(a). How did this incident effect your business relationship with your customer?

Adjourned Weakened Not Influenced Improved

(b). How did this incident effect your business relationship with your service provider?

Adjourned Weakened Not Influenced Improved

IV.(a).Please specify this customer's significance to your company with regard to transaction size. (1: not significant; 10:very significant)

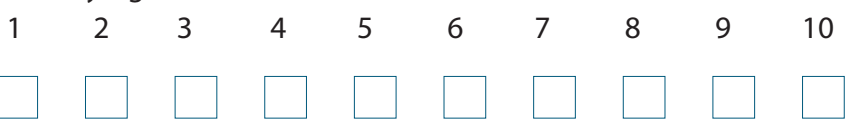

(b). How many years have you been working with this customer?

less than $1 \quad 01-3 \quad 04-6 \quad 07-10 \quad$ more than 10

\section{REFERENCES}

Andrejić, M., Kilibarda, M., 2017. Failure Management in Distribution Logistics Applying FMEA Approach.

Bagozzi, R.P., 1975. Marketing as Exchange. Journal of Marketing, 39(4), p. 32. Available at:

http://dx.doi.org/10.2307/1250593.

Ballou, R. H., 2004. Business Logistics / Supply Chain Management; planning, organizing, and controlling the supply chain. Fifth Edition, Pearson Education International.

Battaglia, D. et al., 2012. Service recovery: a method for assessing performance. Business Process Management Journal, 18(6), pp. 949-963. Available at: http://dx.doi.org/10.1108/14637151211283366.

Bejou, D. \& Palmer, A., 1998. Service failure and loyalty: an exploratory empirical study of airline customers. Journal of Services Marketing, 12(1), pp. 7-22. Available at:

http://dx.doi.org/10.1108/08876049810202339.

Bejou, D., Edvardsson, B. \& Rakowski, J.P., 1996. A Critical Incident Approach to Examining the Effects of Service Failures on Customer Relationships. Journal of Travel Research, 35(1), pp.35-40. Available at: http://dx.doi.org/10.1177/004728759603500106.

Bell, C.R., and Zemke, R.E., 1987. Service breakdown: the road to recovery. Management review, 76(10), pp. 32.

Bienstock, C.C., Mentzer, J.T. \& Bird, M.M., 1996. Measuring Physical Distribution Service Quality. Journal of the Academy of Marketing Science, 25(1), pp. 31-44. Available at:

http://dx.doi.org/10.1177/0092070397251004. 
Bitner, M. J., Booms, B.H., Mohr, L.A., 1994. Critical Service Encounters:The Employee's Viewpoint, Journal of Marketing, 58(4), pp. 95-106. Available at: https://doi.org/10.1177/002224299405800408.

Bitner, M.J., Booms, B.H. \& Tetreault, M.S., 1990. The Service Encounter: Diagnosing Favorable and Unfavorable Incidents. Journal of Marketing, 54(1), pp. 71-84. Available at:

http://dx.doi.org/10.1177/002224299005400105.

Boshoff, C., 1999. Recovsat. Journal of Service Research, 1(3), pp. 236-249. Available http://dx.doi.org/10.1177/109467059913005

Boshoff, C. \& Leong, J., 1998. Empowerment, attribution and apologising as dimensions of service recovery. International Journal of Service Industry Management, 9(1), pp. 24-47. Available at: http://dx.doi.org/10.1108/09564239810199932.

Boshoff, C., 1997. An experimental study of service recovery options. International Journal of Service Industry Management, 8(2), pp. 110-130. Available at: http://dx.doi.org/10.1108/09564239710166245.

Bradley, G. \& Sparks, B., 2012. Explanations: if, when, and how they aid service recovery. Journal of Services Marketing, 26(1), pp. 41-51. Available at: http://dx.doi.org/10.1108/08876041211199715.

Brinsmead, A., 2007. Logistics service recovery and the role of technology. 2007 International Symposium on Communications and Information Technologies. Available at:

http://dx.doi.org/10.1109/iscit.2007.4392228.

Brown, S.W., Cowles, D.L. \& Tuten, T.L., 1996. Service recovery: its value and limitations as a retail strategy. International Journal of Service Industry Management, 7(5), pp.32-46. Available at:

http://dx.doi.org/10.1108/09564239610149948.

Burns, A.C., Williams, L.A. \& "Trey" Maxham, J., 2000. Narrative text biases attending the critical incidents technique. Qualitative Market Research: An International Journal, 3(4), pp.178-186. Available at: http://dx.doi.org/10.1108/13522750010349279.

Chumpitaz Caceres, R. \& Paparoidamis, N.G., 2007. Service quality, relationship satisfaction, trust, commitment and business-to-business loyalty. European Journal of Marketing, 41 (7/8), pp. 836-867. Available at: http://dx.doi.org/10.1108/03090560710752429.

Chell, E., Critical Incident Technique. Essential Guide to Qualitative Methods in Organizational Research, pp. 45-60. Available at: http://dx.doi.org/10.4135/9781446280119.n5.

Chou, C., Hsu, Y. H., and Goo, Y. J., 2009. Service Failures and Recovery Strategies from the Service Provider Perspective. Asia Pacific Management Review, 14(2), pp. 237-249.

Chung-Herrera, B.G., Goldschmidt, N. \& Doug Hoffman, K., 2004. Customer and employee views of critical service incidents. Journal of Services Marketing, 18(4), pp.241-254. Available at:

http://dx.doi.org/10.1108/08876040410542245.

Craighead, C.W., Karwan, K.R. \& Miller, J.L., 2009. The Effects of Severity of Failure and Customer Loyalty on Service Recovery Strategies. Production and Operations Management, 13(4), pp.307-321. Available at: http://dx.doi.org/10.1111/j.1937-5956.2004.tb00220.x.

Dasu, S. \& Rao, J., 2009. A Dynamic Process Model of Dissatisfaction For Unfavorable, Non-Routine Service Encounters. Production and Operations Management, 8(3) pp.282-300. Available at:

http://dx.doi.org/10.1111/j.1937-5956.1999.tb00309.x.

Del Río-Lanza, A.B., Vázquez-Casielles, R. \& Díaz-Martín, A.M., 2009. Satisfaction with service recovery: Perceived justice and emotional responses. Journal of Business Research, 62(8), pp.775-781. Available at: http://dx.doi.org/10.1016/j.jbusres.2008.09.015.

Dua, A. \& Sinha, D., 2019. Quality of multimodal freight transportation: a systematic literature review. World Review of Intermodal Transportation Research, 8(2), p.167. Available at: http://dx.doi.org/10.1504/writr.2019.099136

Durvasula, S., Lysonski, S. \& Mehta, S.C., 2000. Business-to-business marketing Service recovery and customer satisfaction issues with ocean shipping lines. European Journal of Marketing, 34(3/4), pp.433-452. Available at: http://dx.doi.org/10.1108/03090560010311957.

Edvardsson, B., 1992. Service Breakdowns: A Study of Critical Incidents in an Airline. International Journal of Service Industry Management, 3(4), pp. 17-29. Available at: http://dx.doi.org/10.1108/09564239210019450.

Edvardsson, B., 1998. Causes of customer dissatisfaction - studies of public transport by the critical-incident method. Managing Service Quality: An International Journal, 8(3), pp.189-197. Available at: http://dx.doi.org/10.1108/09604529810215675.

Edvardsson, B. \& Roos, I., 2001. Critical incident techniques. International Journal of Service Industry Management, 12(3), pp. 251-268. Available at: http://dx.doi. org/10.1108/eum0000000005520.

Flanagan, J.C., 1954. The critical incident technique. Psychological Bulletin, 51(4), pp.327-358. Available at: http://dx.doi.org/10.1037/h0061470.

Sanches Flores, L.A.F. \& Primo, M.A.M., 2008. Failure Recovery Management in Performance of Logistics Services in a B2B Context: A Case Study Using the 3PL Perspective. Journal of Operations and Supply Chain Management, 1(1), p. 29. Available at:

http://dx.doi.org/10.12660/joscmv1n1p29-40.

Gabbott, M. \& Hogg, G., 1996. The glory of stories: Using critical incidents to understand service evaluation in the primary healthcare context. Journal of Marketing Management, 12(6), pp.493-503. Available at: http://dx.doi.org/10.1080/0267257x.1996.9964431.

Gidener Özaydın, N. G., Güçlüoğulları, E., \& Deveci, D. A., 2015. Typologies of Freight Forwarding Service Failures And Recovery Strategies. Beykoz Akademi Dergisi, 3(2), pp. 25-25. Available at:

http://dx.doi.org/10.14514/byk.m.21478082.2015.3/2.25-54

Gremler, D.D., 2004. The Critical Incident Technique in Service Research. Journal of Service Research, 7(1), pp. 65-89. Available at: http://dx.doi.org/10.1177/1094670504266138.

Grönroos, C., 1988. Service quality: the six criteria of good perceived service. Review of business, 9(3), pp.10.

Grove, S.J. \& Fisk, R.P., 1997. The impact of other customers on service experiences: A critical incident examination of "getting along." Journal of Retailing, 73(1), pp. 63-85. Available at:

http://dx.doi.org/10.1016/s0022-4359(97)90015-4.

Halbheer, D. et al., 2018. Optimizing service failure and damage control. International Journal of Research in Marketing, 35(1), pp. 100-115. Available at: http://dx.doi.org/10.1016/j.ijresmar.2017.11.001. 
Hart, C. W., Heskett, J. L., and Sasser Jr, W. E., 1990. The profitable art of service recovery. Harvard business review, 68(4), pp. 148-156.

Hoffman, K.D., Kelley, S.W. \& Rotalsky, H.M., 1995. Tracking service failures and employee recovery efforts. Journal of Services Marketing, 9(2), pp. 49-61. Available at:

http://dx.doi.org/10.1108/08876049510086017.

Johnston, R. \& Michel, S., 2008. Three outcomes of service recovery. International Journal of Operations \& Production Management, 28(1), pp. 79-99. Available at: http://dx.doi.org/10.1108/01443570810841112.

Hübner, D., Wagner, S. M., \& Kurpjuweit, S., 2018. The service recovery paradox in B2B relationships. Journal of Business \& Industrial Marketing, 33(3), pp. 291-302. Available at:

http://dx.doi.org/10.1108/jbim-03-2016-0055

Johnston, R., 1995. The determinants of service quality: satisfiers and dissatisfiers. International Journal of Service Industry Management, 6(5), pp. 53-71. Available at: http://dx.doi.org/10.1108/09564239510101536.

Johnston, R. \& Michel, S., 2008. Three outcomes of service recovery. International Journal of Operations \& Production Management, 28(1), pp. 79-99. Available at: http://dx.doi.org/10.1108/01443570810841112.

Keaveney, S.M., 1995. Customer Switching Behavior in Service Industries: An Exploratory Study. Journal of Marketing, 59(2), pp.71-82. Available at: http://dx.doi.org/10.1177/002224299505900206.

Kelley, S.W., Hoffman, K.D. \& Davis, M.A., 1993. A typology of retail failures and recoveries. Journal of Retailing, 69(4), pp.429-452. Available at:

http://dx.doi.org/10.1016/0022-4359(93)90016-c.

Koelemeijer, K., 1995. The retail service encounter: identifying critical service experiences. Journal Of Managing Service Quality.

Levesque, T. J., and McDougall, G. H., 2000. Service problems and recovery strategies: an experiment. Canadian Journal of Administrative Sciences/Revue Canadienne des Sciences de l'Administration, 17(1), pp. 20-37. Available at:

http://dx.doi.org/10.1111/cjas.2000.17.issue-1.

Lewis, B.R. \& Spyrakopoulos, S., 2001. Service failures and recovery in retail banking: the customers' perspective. International Journal of Bank Marketing, 19(1), pp.3748. Available at:

http://dx.doi.org/10.1108/02652320110366481.

Lockshin, L. \& McDougall, G., 1998. Service problems and recovery strategies: an examination of the critical incident technique in a business-to-business market. International Journal of Retail \& Distribution Management, 26(11), pp. 429-438. Available at:

http://dx.doi.org/10.1108/09590559810246395.

Michel, S., 2001. Analyzing service failures and recoveries: a process approach. International Journal of Service Industry Management, 12(1), pp. 20-33. Available at:

http://dx.doi.org/10.1108/09564230110382754

Migacz, S.J., Zou, S. \& Petrick, J.F., 2017. The "Terminal" Effects of Service Failure on Airlines: Examining Service Recovery with Justice Theory. Journal of Travel Research, 57(1), pp. 83-98. Available at:

http://dx.doi.org/10.1177/0047287516684979.

Miller, J.L., Craighead, C.W. \& Karwan, K.R., 2000. Service recovery: a framework and empirical investigation. Journal of Operations Management, 18(4), pp. 387-400. Available at:

http://dx.doi.org/10.1016/s0272-6963(00)00032-2.
Mohr, L.A. \& Bitner, M.J., 1995. The role of employee effort in satisfaction with service transactions. Journal of Business Research, 32(3), pp.239-252. Available at: http://dx.doi.org/10.1016/0148-2963(94)00049-k.

Odekerken-Schröder, G. et al., 2000. Moments of sorrow and joy. European Journal of Marketing, 34(1/2), pp.107-125. Available at: http://dx.doi.org/10.1108/03090560010306232

Oflaç, B.S., Sullivan, U.Y. \& Baltacioğlu, T., 2012. An Attribution Approach to Consumer Evaluations in Logistics Customer Service Failure Situations. Journal of Supply Chain Management, 48(4), pp.51-71. Available at: http://dx.doi.org/10.1111/j.1745-493x.2012.03280.x

Ok, C., Back, K.-J. \& Shanklin, C.W., 2005. Modeling Roles of Service Recovery Strategy: A Relationship-Focused View. Journal of Hospitality \& Tourism Research, 29(4), pp.484-507. Available at: http://dx.doi.org/10.1177/1096348005276935.

Olsen, M., and Thomasson, B., 1992. Qualitative Methods in Service Quality Research: An Illustration of the Critical Incident Technique and Phenomenography'. In QUIS3 Conference, pp. 14-17

Özgüven, N., 2008. Hizmet pazarlamasında müşteri memnuniyeti ve ulaştırma sektörü üzerinde biru ygulama. Ege Akademik Bakış (Ege Academic Review), 8(2), pp. 651-682. Available at:

http://dx.doi.org/10.21121/eab.2015221927

Öztürk, S. A., 2000. Hizmet Kalitesi Ölçümünde Yeni Bir Yaklaşım: Kritik Olaylar Tekniği. Anatolia: Turizm Araştırmaları Dergisi, 11, pp. 57-68.

Parasuraman, A., Berry, L. L., \& Zeithaml, V. A., 1991. Refinement and reassessment of the SERVQUAL scale. Journal of retailing, 67(4), p. 420.

Parasuraman, A., Zeithaml, V.A. \& Berry, L.L., 1985. A Conceptual Model of Service Quality and Its Implications for Future Research. Journal of Marketing, 49(4), pp. 41-50. Available at: http://dx.doi.org/10.1177/002224298504900403.

Payne, A., 1993. The essence of services marketing. Prentice Hall.

Perreault, W.D. \& Leigh, L.E., 1989. Reliability of Nominal Data Based on Qualitative Judgments. Journal of Marketing Research, 26(2), p. 135. Available at: http://dx.doi.org/10.2307/3172601.

Rai, D., \& Ozuem, W., 2019. Exploring the relationship between online service failure, recovery strategies and customer satisfaction.

Reis, J., Amorim, M. \& Melão, N., 2019. Multichannel service failure and recovery in a $\mathrm{O} 2 \mathrm{O}$ era: A qualitative multi-method research in the banking services industry. International Journal of Production Economics, 215, pp.24-33. Available at: http://dx.doi.org/10.1016/j.ijpe.2018.07.001.

Reynolds, K. L., \& Harris, L. C., (2005). When service failure is not service failure: an exploration of the forms and motives of "illegitimate" customer complaining. Journal of Services Marketing, 19(5), 321-335. doi:10.1108/08876040510609934.

Rojas, A.R., 2018. SWOT analysis of specialised and transport facilities in the logistics infrastructure of Mexico 2013-2018. World Review of Intermodal Transportation Research, 7(2), p.147. Available at: http://dx.doi.org/10.1504/writr.2018.091254.

Russell, D.M., Swanson, D. \& Blinge, M., 2018. Sustainable logistics and supply chain management: a holistic view through the lens of the wicked problem. World Review of Intermodal Transportation Research, 7(1), p.36. Available at: http://dx.doi.org/10.1504/writr.2018.089517.

Singh, J. \& Wilkes, R.E., 1996. When Consumers Complain: A Path Analysis of the Key Antecedents of Consumer Complaint Response Estimates. Journal of the Academy 
of Marketing Science, 24(4), pp.350-365. Available at: http://dx.doi.org/10.1177/0092070396244006.

Smith, A.K., Bolton, R.N. \& Wagner, J., 1999. A Model of Customer Satisfaction with Service Encounters Involving Failure and Recovery. Journal of Marketing Research, 36(3), pp.356-372. Available at:

http://dx.doi.org/10.1177/002224379903600305.

Solomon, M.R. et al., 1985. A Role Theory Perspective on Dyadic Interactions: The Service Encounter. Journal of Marketing, 49(1), pp. 99-111. Available at: http://dx.doi.org/10.1177/002224298504900110.

Spreng, R.A., Harrell, G.D. \& Mackoy, R.D., 1995. Service recovery: Impact on satisfaction and intentions. Journal of Services Marketing, 9(1), pp. 15-23. Available at:

http://dx.doi.org/10.1108/08876049510079853.

Stauss, B., 1993. Service Problem Deployment: Transformation of Problem Information into Problem Prevention Activities. International Journal of Service Industry Management, 4(2), pp. 41-62. Available at: http://dx.doi.org/10.1108/09564239310037927.

Stauss, B. \& Weinlich, B., 1997. Process-oriented measurement of service quality. European Journal of Marketing, 31(1), pp. 33-55. Available at: http://dx.doi.org/10.1108/03090569710157025.

Swanson, S.R. \& Hsu, M.K., 2009. Critical Incidents in Tourism: Failure, Recovery, Customer Switching, and Word-of-Mouth Behaviors, Journal of Travel \& Tourism Marketing, 26(2), pp. 180-194. Available at: http://dx.doi.org/10.1080/10548400902864800.

Tax, S.S., Brown, S.W. \& Chandrashekaran, M., 1998. Customer Evaluations of Service Complaint Experiences: Implications for Relationship Marketing. Journal of Marketing, 62(2), pp. 60-76. Available at: http://dx.doi.org/10.1177/002224299806200205.

Taylor, S. A., and Baker, T. L., 1994. An assessment of the relationship between service quality and customer satisfaction in the formation of consumers purchase intentions. Journal of retailing, 70(2), pp. 163-178. Available at: https://doi.org/10.1016/0022-4359(94)90013-2

Van Doorn, J. \& Verhoef, P.C., 2008. Critical Incidents and the Impact of Satisfaction on Customer Share. Journal of Marketing, 72(4), pp. 123-142. Available at: http://dx.doi.org/10.1509/jmkg.72.4.123.

Weber, R.P., 1985. Basic Concept Analysis, Sage University Paper Series on Quantitative Applications in the Social Sciences, Beverly Hills and London: Sage Publications, Inc., pp. 7-49.

Webster, C. \& Sundaram, D.S., 1998. Service consumption criticality in failure recovery. Journal of Business Research, 41(2), pp. 153-159. Available at: http://dx.doi.org/10.1016/s0148-2963(97)00004-0.

Weun, S., Beatty, S.E. \& Jones, M.A., 2004. The impact of service failure severity on service recovery evaluations andpost-recovery relationships. Journal of Services Marketing, 18(2), pp. 133-146. Available at: http://dx.doi.org/10.1108/08876040410528737.

White, L. \& Yanamandram, V., 2007. A model of customer retention of dissatisfied business services customers. Managing Service Quality: An International Journal, 17(3), pp. 298-316. Available at:

http://dx.doi.org/10.1108/09604520710744317.

Youngdahl, W. E., and Kellogg, D. L., 1997. The relationship between service customers quality assurance behaviors, satisfaction, and effort: A cost of quality perspective. Journal of Operations Management, 15(1), pp. 19-32. Available at: https://doi.org/10.1016/s0272-6963(96)00097-6.

Zeithaml, V. and Bitner, M.J., 2003. Services Marketing: Integrating Customer Focus across the Firm, 3rd Ed., McGraw-Hill, New York.

Zemke, R., and Bell, C., 1990. Service recovery: Doing it right the second time. Training, 27(6), pp. 42-48.

Zhu, Z., Sivakumar, K. \& Parasuraman, A., 2004. A Mathematical Model of Service Failure and Recovery Strategies. Decision Sciences, 35(3), pp. 493-525. Available at: http://dx.doi.org/10.1111/j.0011-7315.2004.02597.x. 